\title{
AORTIC ORIGIN OF THE RIGHT PULMONARY ARTERY
}

BY

\author{
COLING CARO,* VICTOR C. LERMANDA, AND HAROLD A. LYONS
}

From the Department of Medicine, College of Medicine at New York City, State University of New York and the Kings County Hospital Center, Brooklyn, New York

Received September 21, 1956

The anomalies of the pulmonary arterial circulation have been reviewed (Findlay and Maier, 1951) and classified according to the major vessel of the systemic circulation from which the anomalous vessel originates. This classification does not give recognition to the presence or absence of vascular connections between the affected lung and the lesser circulation. We have found eight reported cases (Table I) of anomalous blood supply to one lung via a single systemic artery arising directly from the aorta, proximal to the origin of the left subclavian artery. In each the normal ipsilateral pulmonary artery was absent. This paper reports one further case.

\section{CASE REPORT}

A 23-year-old man was referred to hospital with a diagnosis of patent ductus arteriosus. His chief complaints were hæmoptysis for two years, and progressive shortness of breath on exertion for one year. A cardiac murmur had been detected at the age of four months. At seventeen years he became aware of shortness of breath on exertion and was advised to have cardiac surgery, but he refused. At no time had he been cyanosed. Hæmoptysis had occurred on more than 50 occasions; (1-2 teaspoons of bright red blood admixed with whiteish-yellow sputum) particularly after physical exertion or in the morning on waking. He was able to walk several miles on the flat but became dyspnœic after climbing two flights of stairs. There was no history of cardiac irregularity or failure.

There was no parental consanguinity and had been no maternal illness during the pregnancy. Delivery was normal and at full term. The patient was the third of nine children. Two siblings died of respiratory infections during the first few months of their lives, and a third died of bronchopneumonia at the age of one year: he was diagnosed clinically as having a cardiac anomaly but there was no necropsy.

\section{Physical Examination}

The patient was well nourished, and well developed. There was no cyanosis and no clubbing of the fingers or toes. The pulse rate was 80 a minute; the rhythm was regular. The blood pressure was $130 / 60 \mathrm{~mm}$. Hg. The jugular venous pressure was not raised.

The trachea was in the midline; the chest excursion was bilaterally symmetrical and examination of the lungs by percussion and auscultation revealed no abnormality.

The maximum cardiac impulse was palpable in the left fifth intercostal space in the mid-clavicular line. The second pulmonic sound was palpable, and there was a faint systolic thrill in this area. There was a loud machinery murmur of maximal intensity in the second left intercostal space, also audible in the third. A diastolic murmur was heard in the fourth left intercostal space; it was not known whether this was the diastolic component of the machinery murmur or a separate murmur.

There were no other abnormal physical findings. The blood count and urine analysis were normal. In the electrocardiogram there were prominent $R$ waves in all leads and deep $S$ waves in V2-5-findings indicative of biventricular hypertrophy.

The postero-anterior roentgenogram of the chest (Fig. 1) showed the right hemithorax to be smaller than the left, with slight displacement of the heart to the right. The left border of the heart was prominent, suggesting left ventricular enlargement. There was also prominence of the pulmonary artery segment and

* Now at the Department of Physiology and Pharmacology, Graduate School of Medicine, University of Pennsylvania, Philadelphia. 
slight widening of the superior mediastinum. The lung fields appeared normal but both the right and the left pulmonary artery shadows were somewhat enlarged. The right root shadow was approximately $3 \mathrm{~cm}$. higher than the left. On fluoroscopy there appeared to be moderate enlargement of the left ventricle, but no enlargement of the left atrium.

Angiocardiography was performed using the method of Robb and Steinberg (1938). In the postero-anterior position, the film exposed at 2 seconds (Fig. 3A) showed slight enlargement of the right atrium and ventricle, a normal pulmonary outflow path, and great dilatation of the main pulmonary artery. Only the left pulmonary artery and its branches were opacified and these vessels were considerably dilated.

The right pulmonary artery became opacified at 8 seconds contemporaneously with the aorta (Fig. 3B). It appeared to arise from the ascending aorta and to have no connection with the main or left pulmonary arteries. The anomalous artery seemed to displace the superior vena cava slightly laterally in its course to the hilum of the right lung. Proximally its calibre was somewhat greater than that of a normal pulmonary artery, but distally its branches were considerably narrowed.

Angiocardiography was repeated in the right anterior oblique position (Fig. 2). The vessel to the right lung again opacified with the aorta. It appeared to arise from the posterior aspect of the ascending aorta at the beginning of the aortic arch. The ductus arteriosus was not demonstrated. There was no evidence of reversal of flow in the ductus-simultaneous opacification of the descending aorta and the pulmonary artery, without opacification of the ascending aorta (Gasul et al., 1953).

The size and site of origin of the vessel to the right lung made it likely that it was an anomalous pulmonary artery, and not a bronchial vessel. The right pulmonary veins became opacified on later films and appeared to pass towards the left atrium.

Bronchography. The arrangement of the bronchi was normal. There were a few areas of 


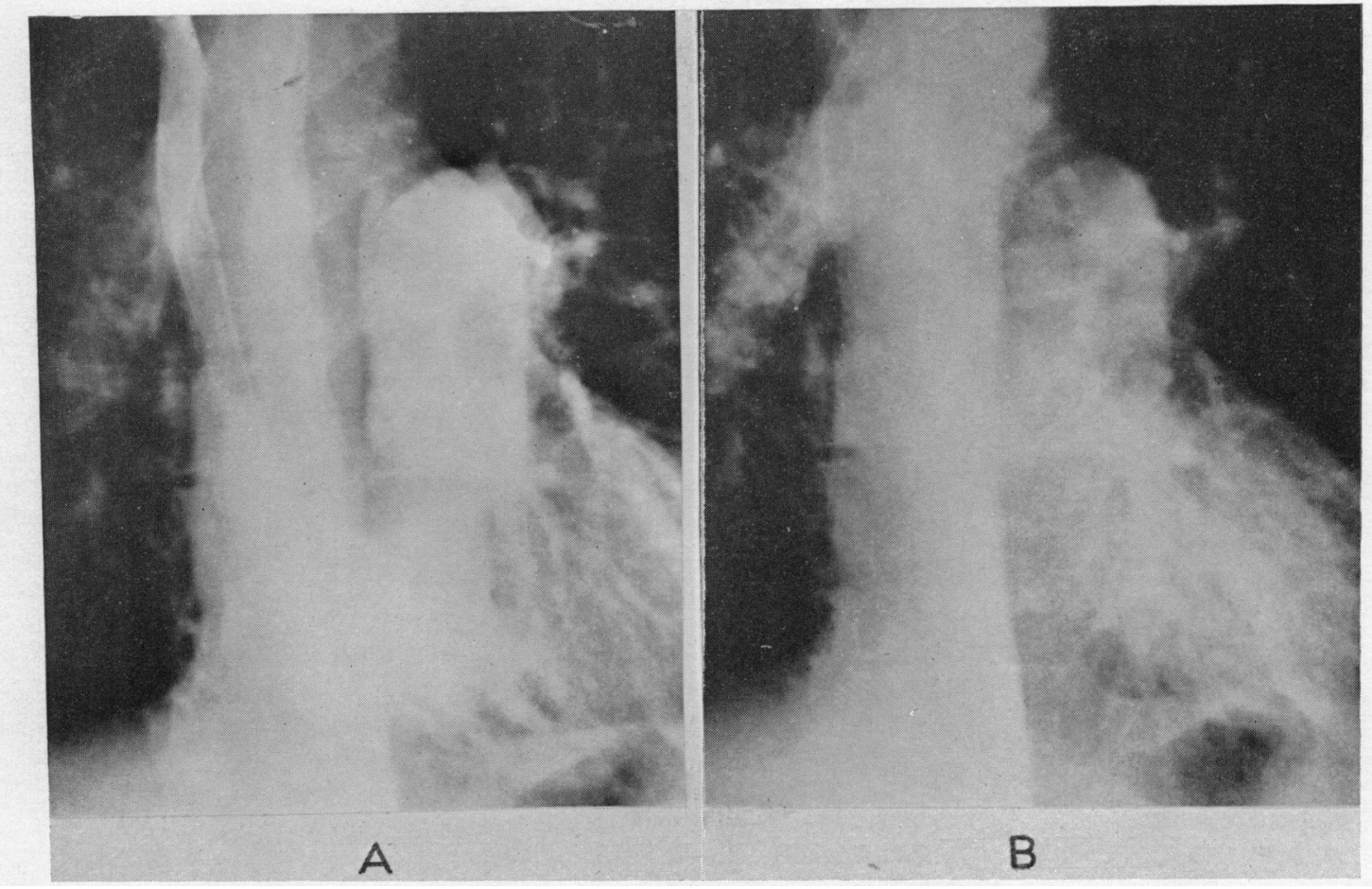

Fig. 3.-Angiocardiograms. (A) At 2 sec. the main P.A. is considerably dilated; only the left P.A. is opacified. (B) At $8 \mathrm{sec}$. the right P.A. appears to arise from the ascending aorta and has no connection with the main P.A.

slight cylindrical bronchial dilatation in the left lower lobe. It was considered unlikely that this minimal bronchiectasis was responsible for the hæmoptyses.

Cardiac Catheterization. Repeated attempts to pass the catheter into the right pulmonary artery were unsuccessful. The blood oxygen saturation in the left pulmonary artery was 14 per cent higher than in the right ventricle. The right ventricular pressure was $57 / 8 \mathrm{~mm}$. Hg. The pressure in the left pulmonary artery was $57 / 33$, and $75 / 39 \mathrm{~mm}$. in the region of the ductus. The pulmonary arteriolar resistance was raised to 570 dynes $\mathrm{cm}^{-5}$.

The blood oxygen saturation was 60 in the right atrium and 68 per cent in the right ventricle. This difference was interpreted as due to either slight pulmonary insufficiency (Cournand, 1949) or to a small left-to-right shunt via a ventricular septal defect. The oxygen saturation of systemic arterial blood was 96 per cent. The right ventricular output was calculated to be 4.0 and the total pulmonary flow $7 \cdot 4$, indicating a left-to-right shunt of $3 \cdot 4$ litres a minute.

In order to confirm that there was no reversal of flow in the ductus the oxygen saturation of left brachial and femoral arterial blood was determined with the patient at rest, during exercise, and after breathing 10 per cent oxygen. During exercise only, the saturation of the femoral artery sample was $2 \cdot 2$ per cent lower than that of blood in the brachial artery. This was not considered significant of reversal of the shunt.

Pulmonary Function Studies. There was no disturbance of combined ventilation. On bronchospirometry the right lung contributed only 39 per cent of the tidal volume. When room air was supplied to both lungs, the right did not participate in oxygen uptake although there was some elimination of carbon dioxide.

These observations are similar to those recorded by other workers in patients (Madoff et al., 1952; Roh et al., 1949) and in experimental animals (Bloomer et al., 1949), where one lung was 
perfused solely by systemic arterial blood. They were considered to have confirmed the angiocardiographic and catheterization findings that the normal right pulmonary artery was absent and that the right lung received its blood supply via an anomalous systemic artery from the aorta. When pure oxygen was supplied to both lungs, 26 per cent of the $\mathrm{O}_{2}$ uptake was by the right. (Unfortunately the arterial $\mathrm{O}_{2}$ saturation at this time was not estimated). This was interpreted as indicating that the right lung was capable of function under conditions of increased oxygen tension.

\section{Surgical TReatment}

Surgery was undertaken for the following reasons. (1) There was a history of progressive exertional dyspnœea. (2) There was no significant evidence of reversal of flow in the ductus arteriosus and its closure was considered advisable. (3) Intrapulmonary hæmorrhage has been reported in similar cases (White, 1950; Ambrus, 1936) and the history of recurrent hæmoptyses was regarded as an important consideration for interrupting the systemic arterial supply to the right lung. (4) The right lung had been demonstrated to be capable of gas exchange under certain conditions. It was hoped that a functional lung might result if its vascular tree were anastomosed to the lesser circulation.

Operative Procedure. The chest was entered via a long trans-sternal incision through both third intercostal spaces. The arrangement of the arteries arising from the aortic arch was normal. The ductus arteriosus was in the usual position and measured about $1 \mathrm{~cm}$. in diameter and $2 \mathrm{~cm}$. in length. It was manually occluded for two minutes and since this was well tolerated, with a $10 \mathrm{~mm}$. $\mathrm{Hg}$ rise in the diastolic pressure, it was divided. No thrill was palpable anywhere after occlusion of the ductus.

The right side of the ascending aorta was then explored. The artery that had been demonstrated by angiocardiography was found in its predicted location, at the start of the arch of the aorta, and about $3 \mathrm{~cm}$. proximal to the origin of the innominate artery (Fig. 4A). The anomalous vessel measured about $1.5 \mathrm{~cm}$. at its point of origin but was narrowed by an abrupt funnel-shaped kinking to a diameter of $0.5 \mathrm{~cm}$., with a post-stenotic dilatation to a diameter of $3 \mathrm{~cm}$. The anomalous vessel was clamped next to the aorta and the proximal stump was closed. The stenotic portion was resected.

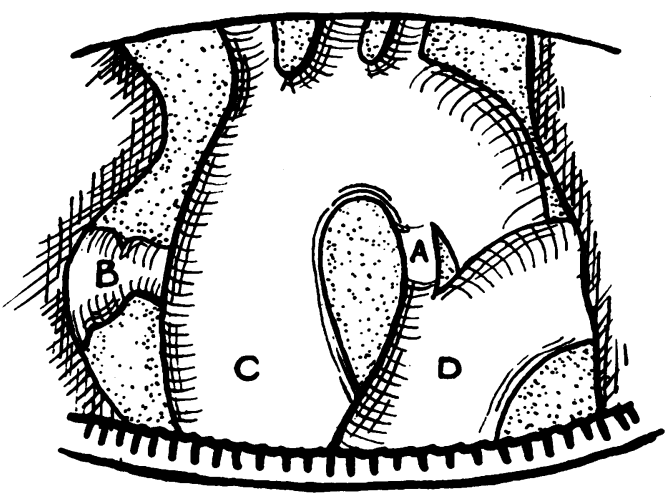

A

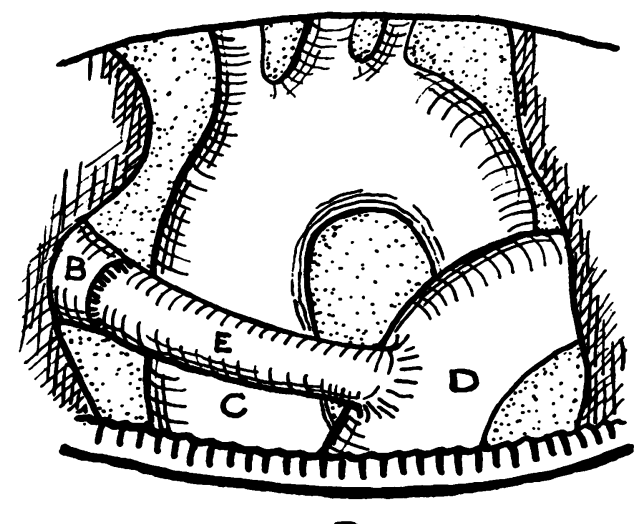

B

FIG. 4.-(A) The appearance at thoracotomy. (B) After division of the ductus arteriosus and completion of the anastomosis. $A=$ ductus arteriosus; $B=$ anomalous right $P . A . ; \quad C=$ ascending aorta; $D=$ main pulmonary artery ; $\mathrm{E}=$ anastomosis of anomalous vessel to main $\mathbf{P} . \mathbf{A}$.

An Ivalon graft was anastomosed end-to-end to the right pulmonary artery and the proximal end of the graft was swung into position anterior to the superior vena cava and ascending aorta. An end-to-side anastomosis was made between it and the main pulmonary artery about $5 \mathrm{~cm}$. proximal to the site of origin of the ductus arteriosus (Fig. 4B). Pulsations were felt in the graft after the clamps were removed and there appeared to be good pulmonary blood flow into the right and left lungs. Biopsies were taken from the middle lobe on the right lung and from the lingula.

The patient regained consciousness immediately after the chest had been closed. Despite blood replacement and intravenous nor-adrenalin his blood pressure did not rise above $90 \mathrm{~mm}$. and he died suddenly 
about five hours after the completion of the operation. Cardiac massage was unsuccessful. All vascular closures and anastomoses were intact but the left pleural space contained about $1000 \mathrm{ml}$. of blood and there was a large hæmatoma in the left chest wall. The intrathoracic bleeding had apparently come from a lacerated intercostal artery. Permission for necropsy was refused.

Pathological Report on the Biopsies of the Right and Left Lungs. The broncho-alveolar and interstitial structure of the lung was equally well formed in both subpleural biopsy fragments and there was no alteration in the structure or distribution of capillaries in either biopsy. In the right lung small muscular arteries and some arterioles showed moderate concentric fibromuscular medial thickening and marked eccentric fibroelastic intimal thickening. Elastic laminæ were multiplied and markedly frayed. These changes especially involved bronchiolar vessels and were slight in arterioles near respiratory bronchioles and in subpleural vessels (Fig. 5A). Arteries and arterioles in the left lung showed only equivocal endothelial and muscular thickening (Fig. 5B).

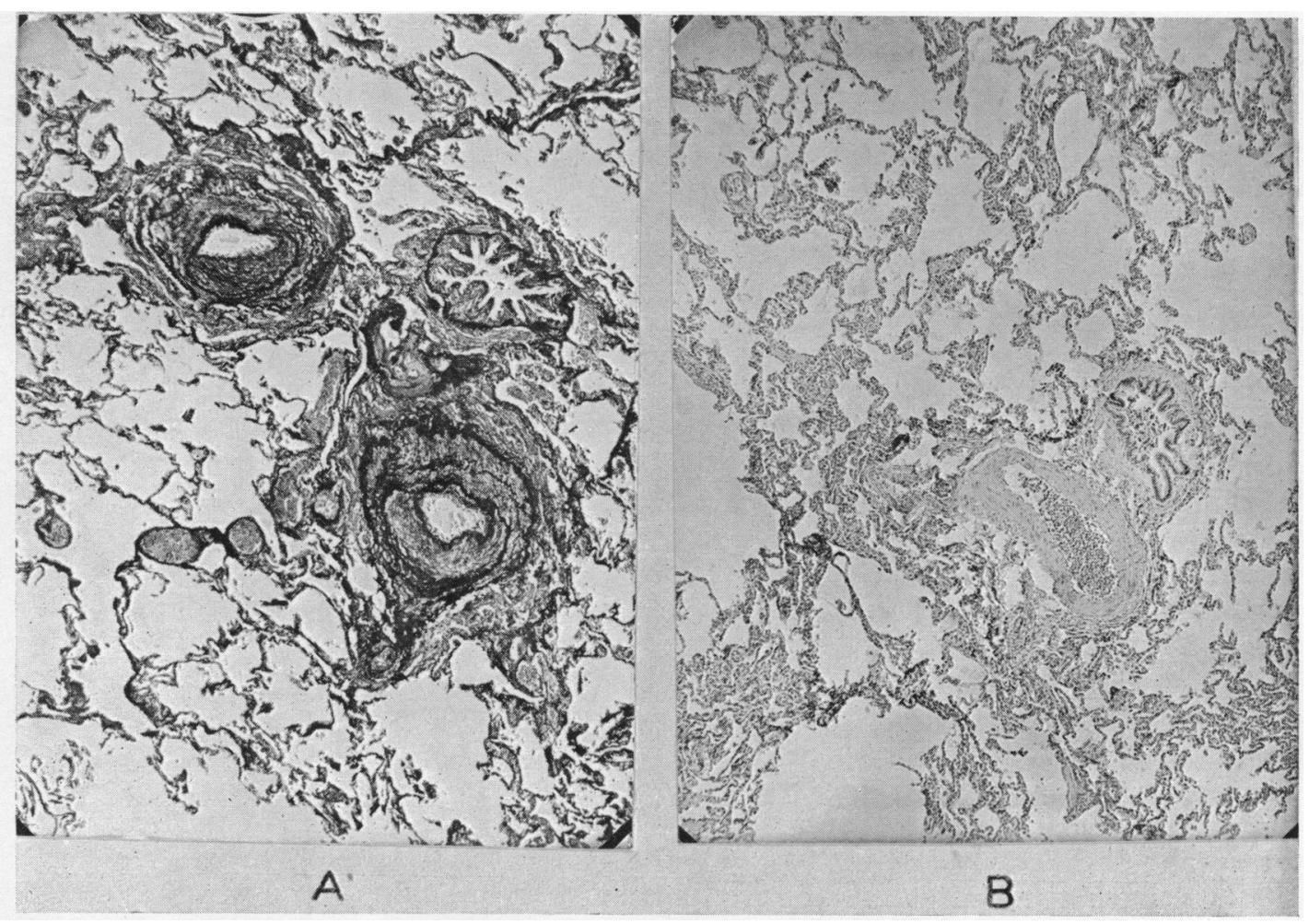

Fig. 5.-(A) Biopsy of the right middle lobe. $\times 32 . \quad(B)$ Biopsy of the lingula. $\quad \times 32$.

\section{Discussion}

Embryology. The developmental anomaly responsible for aortic origin of a main branch of the pulmonary artery is not clearly established. In the human embryo at about $5 \mathrm{~mm}$., the truncus ridges grow to fuse in the midline and divide the truncus arteriosus into the aorta and pulmonary artery. The sixth aortic arches, the precursors of the two main branches of the pulmonary artery, arise from the dorsal aspect of the truncus arteriosus, close to the mid-sagittal plane.

The abnormality may be a consequence of asymmetric origin of one of the sixth aortic arches from the truncus arteriosus (Fig. 6A) or an asymmetric anlage of one of the truncus ridges (Fig. 6B). The former theory appears probable in our case. Asymmetry of the aortico-pulmonary septum is likely to be associated with an over-riding aorta and hypoplasia of the pulmonary artery, with 

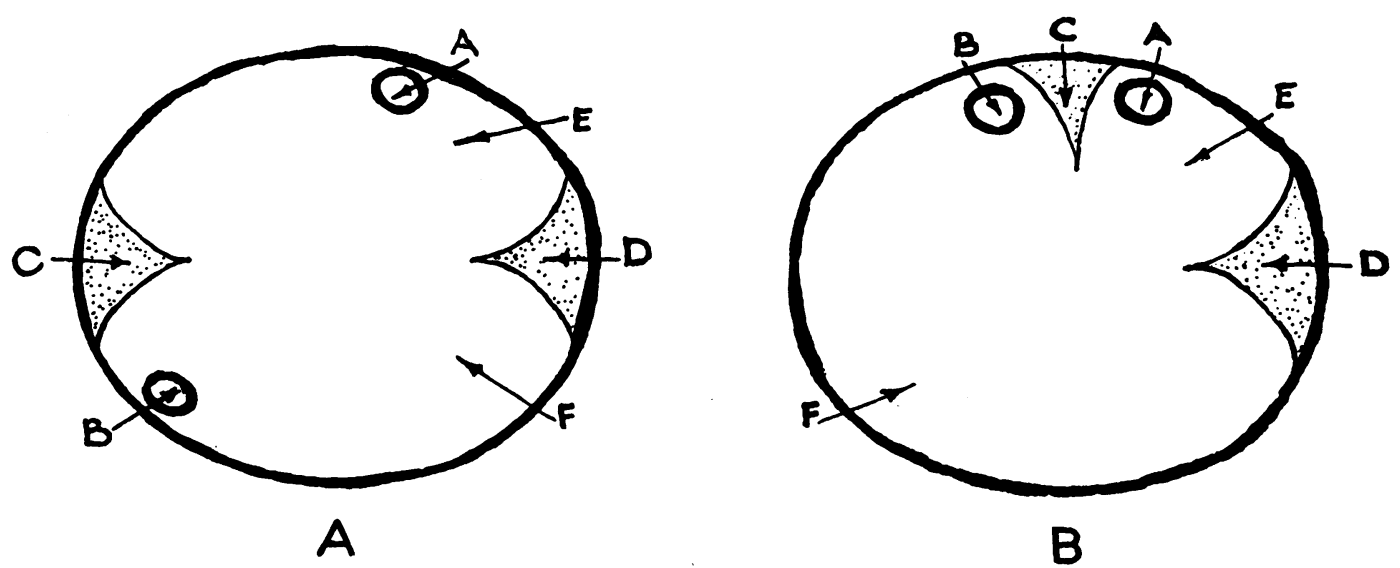

FIG. 6.-(A) Schematic representation of assymetric origin of right sixth aortic arch. (B) Schematic representation of assymetric origin of right truncus ridge. $A=$ future left pulmonary artery; $B=$ future right pulmonary artery; $C=$ right truncus ridge; $D=$ left truncus ridge; $E=$ future main pulmonary artery; $F=$ future aorta.

the additional possibility of a ventricular septal defect. These anomalies were not thought to be present.

Atresia of the proximal connection of the right sixth aortic arch and persistence of its distal connection to the dorsal aorta might explain anomalous origin of the right pulmonary artery. Under these circumstances the anomalous vessel might be expected to arise from the right subclavian artery. Several instances of this have been recorded (Findlay and Maier, 1951).

Review of Similar Cases. The cases we have selected (Table I) conform to one of the categories suggested by Findlay and Maier. In each there was a single anomalous artery to one lung which originated from the aorta proximal to the origin of the left subclavian artery. In addition, however, in every instance the normal ipsilateral pulmonary artery was absent. We believe that their classification should be modified to give recognition to this further abnormality. The vascular anomaly is potentially correctable. But these cases pose a problem which is not present where there is a dual circulation to the lung - that of determining whether the peripheral vascular connections are consistent with gas exchange.

In none of the eight cases was there any characteristic physical finding. A feature of interest in ours was a slight reduction in the size of the hemithorax on the side of the anomalous artery. This has been reported in patients with absence of a main branch of the pulmonary artery (Madoff et al., 1952; Flynn et al., 1954).

Cyanosis was recorded in four cases; but was only present from birth in one where the transverse aortic arch was absent and the descending aorta received its blood supply from the ductus arteriosus. Cyanosis was reported terminally in the other three, two of whom appear to have died of pneumonia.

Life expectancy appears to be poor for six of the eight cases died within the first few months of life. There was, however, pathological evidence of pneumonia in three: the use of antibiotics may improve the prognosis, but pneumonia developing in the only functioning lung must have grave consequences.

A congenital cardiovascular anomaly was known to be present in all but one case. Findlay and Maier observed that there were significant associated cardiovascular anomalies in 75 per cent of cases where the origin of the anomalous pulmonary vessel from the systemic arterial system was above the level of the lung roots, but in only 16 per cent of those where the abnormal pulmonary vessel arose below this level.

The most common additional anomaly was a patent ductus arteriosus. Including our own 
TABLE I

Cases of Aortic Origin of One Pulmonary Artery with Absence of Normal IPSILATERAl Pulmonary ArTery

\begin{tabular}{|c|c|c|c|c|c|c|}
\hline \multirow{2}{*}{ Author } & \multirow{2}{*}{$\begin{array}{l}\text { Age } \\
\text { and } \\
\text { sex }\end{array}$} & \multirow{2}{*}{$\begin{array}{l}\text { Clinical } \\
\text { history }\end{array}$} & \multirow{2}{*}{ Physical signs } & \multicolumn{3}{|c|}{ Necropsy findings } \\
\hline & & & & $\begin{array}{l}\text { Anomalous vessel, } \\
\text { origin and diameter }\end{array}$ & $\begin{array}{l}\text { Associated } \\
\text { anomalies }\end{array}$ & Lungs \\
\hline $\begin{array}{l}\text { Fraentzel, } \\
\quad 1868\end{array}$ & $\frac{25 \mathrm{yr}}{\mathrm{F}}$ & $\begin{array}{l}\text { Progressive } \\
\text { dyspnœa } \\
\text { and } \\
\text { œdema } \\
\text { for } 6 \mathrm{mo} .\end{array}$ & $\begin{array}{l}\text { Kyphoscoliosis, } \\
\text { cyanosis, } \\
\text { large heart. } \\
\text { Murmurs- } \\
\text { apical P.S.M., } \\
\text { lt. para- } \\
\text { sternal S.M. } \\
\text { and D.M. }\end{array}$ & $\begin{array}{l}\text { Rt. P.A. from aorta } \\
\text { close to start of } \\
\text { arch. } \\
2 \text { finger breadths }\end{array}$ & $\begin{array}{l}\text { Aortico-pulmonary } \\
\text { septal defect }\end{array}$ & $\begin{array}{l}\text { Collapse of basal } \\
\text { segments of } \\
\text { rt. lower lobe }\end{array}$ \\
\hline $\begin{array}{c}\text { Thomas, } \\
1941\end{array}$ & $3 \underset{\mathrm{F}}{3 \mathrm{mo}}$ & $\begin{array}{l}\text { Cough and } \\
\text { fever for } \\
3 \text { days }\end{array}$ & $\begin{array}{l}\text { Dyspnœic and } \\
\text { cyanosed. } \\
\text { Loud S. and } \\
\text { D.M. }\end{array}$ & $\begin{array}{l}\text { Lt. P.A. from trans- } \\
\text { verse aortic arch, } \\
\text { to left of left in- } \\
\text { nominate. } \\
\text { Size not recorded }\end{array}$ & $\begin{array}{l}\text { Rt. aortic arch; ab- } \\
\text { sent ductus; ab- } \\
\text { sent pulm. valve; } \\
\text { V.S.D.; poten- } \\
\text { tially P.F.O. }\end{array}$ & $\begin{array}{l}\text { Broncho- } \\
\text { pneumonia }\end{array}$ \\
\hline $\begin{array}{r}\text { Bopp, } \\
1949\end{array}$ & $7 \underset{\mathrm{F}}{7 \mathrm{mo}}$ & $\begin{array}{l}\text { Dyspnœic } \\
\text { from } \\
\text { birth }\end{array}$ & $\begin{array}{l}\text { Markedly en- } \\
\text { larged heart. } \\
\text { Loud S.M. } \\
\text { over all } \\
\text { valve areas }\end{array}$ & $\begin{array}{l}\text { Rt. P.A. from as- } \\
\text { cending aorta. } \\
0.6 \mathrm{~cm} \text {. }\end{array}$ & $\begin{array}{l}\text { P.D.A.; vessels from } \\
\text { transverse aorta, } \\
\text { proximal to distal, } \\
\text { rt. carotid, lt. car- } \\
\text { otid, lt. subcl., rt. } \\
\text { subcl.; vascular } \\
\text { ring }\end{array}$ & $\begin{array}{l}\text { Lt.: congestion } \\
\text { and œdema } \\
\text { Rt.: Increased } \\
\text { peri-arterial } \\
\text { connective } \\
\text { tissue }\end{array}$ \\
\hline $\begin{array}{l}\text { Sikl, } \\
\quad 1952\end{array}$ & $4 \underset{\mathrm{M}}{4 \mathrm{mo}}$ & $\begin{array}{l}\text { Cough and } \\
\text { fever, } 6 \\
\text { days, } \\
\text { murmur } \\
\text { since } \\
\text { birth }\end{array}$ & $\begin{array}{l}\text { Râles through- } \\
\text { out left lung. } \\
\text { Loud apical } \\
\text { S.M. }\end{array}$ & $\begin{array}{l}\text { Rt. P.A. from as- } \\
\text { cending aorta. } \\
0.5 \mathrm{~cm} \text {. }\end{array}$ & None & $\begin{array}{l}\text { Lt.: Pneumonic } \\
\text { consolidation } \\
\text { Rt.: Structure } \\
\text { normal, patchy } \\
\text { consolidation }\end{array}$ \\
\hline $\begin{array}{l}\text { Sikl, } \\
\quad 1952\end{array}$ & \begin{tabular}{|c|} 
Still- \\
born, \\
full \\
term \\
Sex \\
not \\
re- \\
corded
\end{tabular} & & & $\begin{array}{l}\text { Lt. } P . A . \text { from as- } \\
\text { cending aorta. } \\
0.3 \mathrm{~cm} .\end{array}$ & $\begin{array}{l}\text { V.S.D.; overriding } \\
\text { aorta; rt. aortic } \\
\text { arch; reversal of } \\
\text { main cranial } \\
\text { branches; bi- } \\
\text { cuspid pulm. valve; } \\
\text { absent ductus }\end{array}$ & $\begin{array}{l}\text { Lobar anatomy } \\
\text { normal. Lungs } \\
\text { atelectatic }\end{array}$ \\
\hline $\begin{array}{c}\text { Jew and } \\
\text { Gross, } \\
1952\end{array}$ & $\begin{array}{c}53 \mathrm{hr} . \\
\mathrm{M}\end{array}$ & $\begin{array}{l}\text { Cyanosis } \\
\text { from } \\
\text { birth }\end{array}$ & Systolic murmur & $\begin{array}{l}\text { Rt. P.A. from as- } \\
\text { cending aorta. } \\
3.5 \mathrm{~cm} \text {. }\end{array}$ & $\begin{array}{l}\text { P.F.O.; V.S.D.; ab- } \\
\text { sent transverse } \\
\text { aortic arch; } \\
\text { P.D.A. }\end{array}$ & Not reported \\
\hline $\begin{array}{r}\text { Maier, } \\
1954\end{array}$ & $4 \underset{\mathrm{F}}{4 \mathrm{mo}}$ & $\begin{array}{l}\text { Cyanosis } \\
\text { and } \\
\text { dyspnœa }\end{array}$ & $\begin{array}{l}\text { Large heart, } \\
\text { S.M., râles at } \\
\text { bases }\end{array}$ & $\begin{array}{l}\text { Rt. P.A. from as- } \\
\text { cending aorta. } \\
2 \cdot 7 \mathrm{~cm} \text {. }\end{array}$ & $\begin{array}{l}\text { P.F.O.; It. common } \\
\text { carotid from } \\
\text { innominate } \\
\text { artery }\end{array}$ & $\begin{array}{l}\text { Pneumonia and } \\
\text { irregular } \\
\text { hæmorrhagic } \\
\text { areas, both } \\
\text { lungs }\end{array}$ \\
\hline $\begin{array}{r}\text { White, } \\
1950\end{array}$ & $\begin{array}{c}\text { Alive } \\
\text { aet. } \\
32 \mathrm{yr} . \\
\mathrm{F}\end{array}$ & $\begin{array}{l}\text { Hæmoptysis } \\
8 \text { years, } \\
\text { especially } \\
\text { after ex- } \\
\text { ertion. } \\
\text { Murmur } \\
\text { since age } \\
3 \text { years }\end{array}$ & $\begin{array}{l}\text { Heart not en- } \\
\text { larged, pul- } \\
\text { monic second } \\
\text { sound ac- } \\
\text { centuated. } \\
\text { Loud apical } \\
\text { P.S.M. }\end{array}$ & $\begin{array}{l}X \text {-rays. } \\
\text { Prominent P.A. an } \\
\text { density in lt. periphe } \\
\text { Operative findings. } \\
\text { Lt. P.A. from aortic } \\
\text { rhage into lung sub } \\
\text { atheromatous branch }\end{array}$ & $\begin{array}{l}\text { hilar shadows. Are } \\
\text { al lung field. } \\
\text { rch. Lt. upper lobe re } \\
\text { stance, apparently fror } \\
\text { of the anomalous vesse }\end{array}$ & $\begin{array}{l}\text { of increased } \\
\text { sected. Hæmor- } \\
\text { m rupture of an } \\
\text { l. }\end{array}$ \\
\hline
\end{tabular}


case, this lesion was present in three of the six cases with anomalous right pulmonary artery, possibly a significant association. One of the remaining cases with a right-sided lesion had an aortico-pulmonary septal defect. The ductus was absent in two of the three cases where the anomaly was on the left.

Diagnosis. Hæmoptysis occurring after exertion may be significant. The conventional radiogram of the chest is likely to be normal, although there was slight elevation of the right root shadow in our case. At present it would appear that angiocardiography provides the only means of detecting this rare anomaly. Cardiac catheterization and bronchospirometry supplied confirmatory evidence and permitted study of the disturbed physiology.

Physiology. We considered that the limited gas exchange observed on the right side, when our patient breathed 100 per cent oxygen, was consistent with a normal alveolar capillary relationship. Moreover, he did not become cyanosed after the anomalous artery was anastomosed to the pulmonary circulation. This probably indicated that the right lung began to contribute to oxygen uptake and was not functioning as a veno-arterial shunt. Differential diffusion studies were not performed, but might have enabled us to assess better the functional potential of the right lung.

\section{SUMMARY}

Aortic origin of the right pulmonary artery was diagnosed by angiocardiography in a patient with patent ductus arteriosus. Confirmatory procedures were performed and surgical correction attempted.

The reported cases are reviewed and a modification of the method of classification suggested. The high incidence of associated patent ductus arteriosus is noted.

We are indebted to Dr. M. M. Newman for the surgical aspects of the case, to Dr. V. Bleisch for the pathological report, and to Dr. G. Talbert of the Department of Embryology.

Drs. Garrett, Shibuya, and Pereyma assisted us with the translation of references. The patient was referred to us by Dr. Fontanetta of Greenpoint Hospital.

\section{REFERENCES}

Ambrus, G. (1936). J. tech. Meth., 15, 103.

Bloomer, W. C., Harrison, W., Lindskog, R. C., and Liebow, A. A. (1949). Amer. J. Physiol., $157,317$.

Bopp, Von F. (1949). Zentrabl. allg. Path. Anat., 85, 155.

Cournard, A., Baldwin, Janet S., and Himmelstein, A. (1949). Cardiac Catheterisation In Congenital Heart Disease. The Commonwealth Fund, New York.

Findlay, C. W., and Maier, H. C. (1951). Surgery, 29, 604.

Flynn, J. E., Siebens, A. A., and Williams, S. F. (1954). Amer. J. med. Sci., $228,673$.

Fraentzel, O. (1868). Arch. Path. Anat., 43, 420.

Gasul, B. M., Weiss, H., Fell, E. H., Dillon, R. F., Fisher, D. L., and Marienfeld, C. J. (1953). Amer. J. Dis. Child., 85, 404.

Jew, E. W., and Gross, P. (1952). A.M.A. Arch. Path., 53, 191.

Madoff, I. M., Gaensler, E. A., and Strieder, J. W. (1952). New Engl. J. Med., $247,149$.

Maier, H. C. (1954). J. Thoracic Surg., 28, 145.

Robb, G. P., and Steinberg, I. (1938). J. clin. Invest., 17, 507.

Roh, E., Greene, D. G., Himmelstein, A., Humphreys, G. H., and Baldwin, E. de F. (1949). Amer. J. Med., 6, 795.

Sikl, H. (1952). Casop. Lek. Cesk., 91, 1366.

Thomas, H. W. (1941). J. tech. Methods, 21, 58.

White, P. D. (1950). New Engl. J. Med., 242, 258; and personal communication (1956). 